\title{
Epiphytic Weeds Control by Root Infusion Method in Oil Palm
}

\author{
DOI: $10.18196 /$ pt.v10i1.10802 \\ Edyson*, Fitrah Murgianto, Adhy Ardiyanto \\ Bumitama Gunajaya Agro Research Center, \\ Jl. Tjilik Riwut KM 125, Desa Pundu, Kecamatan Cempaga Hulu, Kabupaten Kotawaringin Timur, Kalimantan Tengah 74354, Indonesia \\ *Corresponding author, email: edyson@bumitama.com
}

\begin{abstract}
Epiphytic weeds living on oil palm trunks will complicate harvesting activities. In addition, the presence of this weed can increase the risk of accidents being hit by fruit during harvesting. The objective of this research was to obtain herbicide and its efficient concentrations to control epiphytic weeds using root infusion method. The research was arranged in a single factor completely randomized design (CRD) with five treatments and five replications. Active ingredients of herbicide that used were methyl metsulfuron at a concentration of $20 \%, 30 \%$, and $40 \%$, glyphosate 30\%, and triclopyr + diesel fuel at a ratio of 1:19. All treatments except triclopyr were diluted in $100 \mathrm{ml}$ water for each epiphytic weed. Weed mortality rate (\%) was observed every week for one month. The results showed that a solution of 30\% methyl metsulfuron herbicide in $100 \mathrm{ml}$ of water and 30\% glyphosate in $100 \mathrm{ml}$ of water was the most optimal treatment in controlling epiphytic weeds. Cutting the entire suction root of epiphytic weeds can increase the chance of weed mortality. Keywords: Epiphytic weed, Herbicide, Oil palm, Root infusion
\end{abstract}

\section{ABSTRAK}

Gulma epifit yang hidup di batang kelapa sawit akan mempersulit kegiatan panen. Selain itu, keberadaan gulma ini dapat meningkatkan resiko kecelakaan kerja berupa tertimpanya pemanen oleh buah yang diturunkan. Penelitian ini bertujuan untuk menemukan bahan aktif herbisida dan konsentrasi yang tepat untuk mengendalikan gulma epifit dengan metode infus akar. Penelitian ini menggunakan Rancangan Acak Lengkap (RAL) faktor tunggal dengan lima perlakuan dan lima ulangan. Bahan aktif herbisida yang digunakan adalah larutan metil metsulfuron dengan konsentrasi 20\%, 30\%, 40\%, glifosat 30\%, dan triklopir + solar dengan perbandingan 1:19. Semua perlakuan kecuali triklopir dilarutkan dengan air 100 ml pada masing-masing gulma epifit. Tingkat kematian gulma (\%) diamati setiap minggu selama satu bulan. Hasil penelitian menunjukkan bahwa larutan herbisida metil metsulfuron $30 \%$ dalam 100 ml air dan glifosat 30\% dalam 100 ml air merupakan perlakuan yang paling optimal dalam mengendalikan gulma epifit. Pemotongan seluruh akar hisap gulma epifit dapat meningkatkan peluang kematian gulma dibandingkan dengan tanpa pemotongan akar yang lain.

Kata kunci: Gulma epifit, Herbisida, Infus akar, Kelapa sawit.

\section{INTRODUCTION}

Weeds are plants that can harm cultivated plants either directly or indirectly. The presence of weeds in oil palm plantations must be controlled so as not to interfere with operational activities and cause a decrease in production. Controlling weeds in the planting area, harvesting path, and yield shelters (TPH) is a routine maintenance program carried out with rotation and certain herbicides. Not only living in the soil, but weeds can also grow and attach to the stems of oil palm plants. Weeds growing on oil palm trunks are known as epiphytic weeds (Essandoh et al., 2011). These weeds live by depending on oil palm plants but do not absorb nutrients from their host plant (Compton \& Musgrave, 1993). Epiphytic weeds absorb nutrients by competing for nutrients in the soil when fertilization is applied to oil palm plantations. Epiphytic weeds have better adaptability to water deficits (Adibah and Ainuddin, 2011). Thus, it enhances water competition with main crops. Epiphytic weeds can multiply rapidly through the ability to produce high seeds and allow them to spread to other areas (Bartoli et al., 1993).

Epiphytic weeds commonly found in oil palm plantations are ferns, banyan (Ficus sp), and woody weeds (Ginting et al., 2004). Banyan roots and

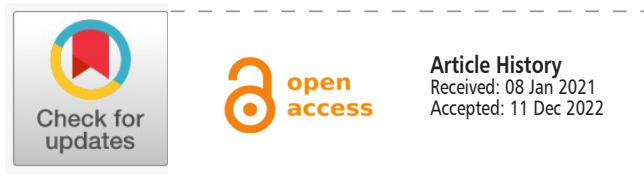


woody weeds that live in epiphytes will wrap around the oil palm trunk until it enters the ground to find water and sources of nutrition. In large numbers and with large sizes, the presence of these weeds is able to break the stems of the plants on which they grow (Bayu et al., 2004). This weed can grow at the bottom, middle, and top of the oil palm trunk.

This can happen with the help of birds landing on the remaining pieces of the midrib attached to the oil palm trunk so that the seeds carried by the birds then germinate and grow. The growth of epiphytic weeds in the middle or top of the oil palm trunk is supported by the organic materials accumulated in the former pieces of oil palm fronds (Sofiyanti, 2013). The organic materials become the initial media for the growth of epiphytic weeds that develop through seeds. Weed transfer by birds (ornitochori) generally occurs in weeds that produce seeds (Mangoensoekarjo \& Soejono, 2015). Several bird species reported to eat Ficus sp seeds are common myna (Acridotheres tristis), zebra doves (Geopelia striata), spotted doves (Streptopelia chinensis), and sparrows (Passer domesticus) (Starr et al., 2003). Several species of these bird species are reported to live and thrive in oil palm plantations (Kissinger et al., 2016; Ahmad et al., 2016; Seprido, 2020).

The presence of epiphytic weeds can disturb the harvest process, especially on tall trees. It causes difficulty for harvesters because the oil palm fruits are hindered by the shade of epiphytic weeds, thereby resulting in reduced production. In addition, the presence of these weeds can also increase the risk of work accidents for harvesters. Harvested fruit can swerve when it falls due to colliding with epiphytic weed stems and can hit workers. Incidents like this can be dangerous for oil palm harvest workers. This weed is commonly found in plantations located not far from the forest and will grow and develop on oil palm plants that are more than 15 years old
(Kuvaini, 2011). Epiphytic weed control policies have been adopted by several oil palm plantations for years with the aim of simplifying the harvesting process (Ferwerda, 1977).

Epiphytic weed can be controlled manually and chemically. Control by cutting or pulling does not show good results. Manual control by pulling or slashing can be done when the epiphytic weeds are still small, growing at the base of the oil palm trunk. The big-size weeds will be more effectively controlled using chemical methods through the foliar spray and stem smear. However, it is relatively ineffective to control epiphytic weeds growing in the middle or top of the oil palm trunk because they are difficult to reach. Selective herbicides sprayed with a high-pressure spray machine provided effective chemical control (Bartoli et al., 1993). A root infusion is a feasible method expected to provide effective results of epiphytic weed control. The root infusion technique is carried out by dipping the roots of the target plant into a herbicide solution, which is then absorbed by the plant and poisons the target plant. Control by spraying techniques requires expensive costs through pumping machines that must be prepared. Therefore, this study was conducted to obtain active ingredients and effective and efficient concentration of herbicides for epiphytic weed control using root infusion control techniques.

\section{MATERIALS AND METHOD}

The research was conducted from May to August 2020 at the Pundu Nabatindo Estate (PNBE) Palm Oil Plantation, PT Bumitama Gunajaya Agro, Central Kalimantan. The research location is in a block with haplohumods soil type and 22-year-old oil palm plantations. The herbicide's active ingredients used were glyphosate, methyl metsulfuron, triclopyr, diesel fuel, and water as a solvent.

The research was arranged in a single factor com- 
pletely randomized design (CRD) consisting of five treatments with five replications, resulting in a total of 25 experimental units. The treatments tested were 20\% methyl metsulfuron (P1), 30\% methyl metsulfuron (P2), 40\% of methyl metsulfuron (P3), $30 \%$ glyphosate (P4), and triclopyr + diesel at a ratio of 1:19 with a total of $100 \mathrm{ml}$ of solution (P5). All treatments except triclopyr were dissolved with 100 $\mathrm{ml}$ of water on each epiphytic weed.

The herbicide solution was mixed according to the treatment being tested and stirred until it was completely dissolved. The root infusion method was carried out by first finding the main roots or suction roots that spread into the soil. The main roots of the epiphytic weeds were put in a plastic bag containing the herbicide solution according to the treatments and tied tightly using a rubber rope to prevent water from entering the plastic bag, while other roots were cut. Visual observation of weed mortality was made once a week for one month.

Analysis of variance (ANOVA) was performed on the weed mortality rate (\%), continued with the Honest Significant Difference (HSD) test at the 5\% level. Data analysis was carried out with the help of Minitab 18 software and Microsoft Excel 2010.

\section{RESULTS AND DISCUSSION}

Weed Mortality Rate

The results of analysis of variance showed that root-infused herbicide solution significantly affected the mortality rate of epiphytic weeds 1-4 weeks after application (WAA) (Table 1). The treatments showing the most optimal results at 4 WAA were methyl metsulfuron at a concentration of $30 \%$ (P2) and glyphosate at a concentration of 30\% (P4), producing epiphytic weed mortality rates of $88 \%$ and $89 \%$, respectively. This result is

Table 1. Symptoms of the epiphytic weed mortality at one to four weeks after application (WAA)

\begin{tabular}{lccc}
\hline & & & Mortality symptoms (\%) after application \\
\cline { 2 - 4 } Treatments & 1 & 2 & 3 \\
\hline $20 \%$ Methyl metsulfuron (P1) & $5 \mathrm{c}$ & $63 \mathrm{~b}$ \\
$30 \%$ Methyl metsulfuron (P2) & $16 \mathrm{~b}$ & $68 \mathrm{~b}$ \\
$40 \%$ Methyl metsulfuron (P3) & $28 \mathrm{~b}$ & $28 \mathrm{ab}$ & $79 \mathrm{a}$ \\
$30 \%$ Glyphosate (P4) & $9 \mathrm{bc}$ & $38 \mathrm{a}$ & $69 \mathrm{ab}$ \\
Triclopyr + Diesel (1:19) (P5) & $5 \mathrm{c}$ & $28 \mathrm{ab}$ & $39 \mathrm{c}$ \\
\hline
\end{tabular}

Remarks: Means followed by the same letters are not significantly different according to the HSD test at 5\%.

Table 2. Cost analysis of epiphytic weed control

\begin{tabular}{|c|c|}
\hline Treatments & $\begin{array}{l}\text { Cost of material per application } \\
\qquad I D(R)\end{array}$ \\
\hline $\begin{array}{l}\text { 20\% Methyl metsulfuron (P1) } \\
30 \% \text { Methyl metsulfuron (P2) } \\
\text { 40\% Methyl metsulfuron (P3) } \\
\text { 30\% Glyphosate (P4) } \\
\text { Triclopyr + Diesel (1:19) (P5) }\end{array}$ & $\begin{array}{c}2,400 \\
3,600 \\
4,800 \\
660 \\
1,385\end{array}$ \\
\hline
\end{tabular}

in line with the research results of Simanjorang (2003) and Hengki et al. (2018), which showed that the active ingredients methyl metsulfuron and glyphosate could provide a high mortality rate of epiphytic weeds. Epiphytic weed leaves treated with 30\% methyl metsulfuron (P2) and 30\% glyphosate (P4) were almost completely dry, falling off at four
WAA. Meanwhile, the treatment with the lowest mortality at four WAA (25\%) was triclopyr + diesel at a ratio of 1:19 (P5) (Figure 1.).

Early symptoms of weed mortality began to appear in one week after application in all treatments in the form of yellowing and leaf drop. Leaf drop can be seen easily on the soil surface (Figure 2). 

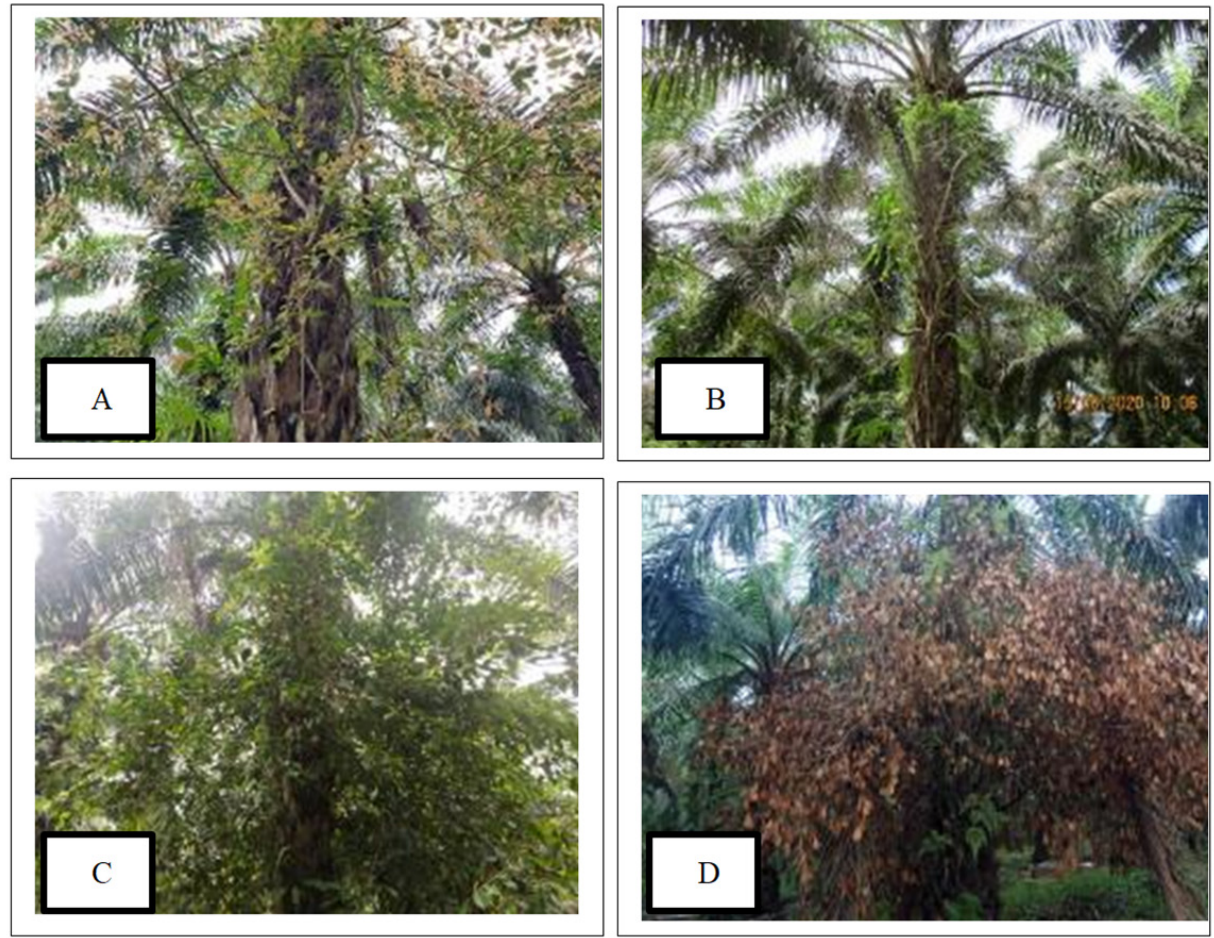

Figure 1. Epiphytic weed condition before (A) and after (B) the application of P2; before (C) and after (D) the application of P4 at four weeks after application
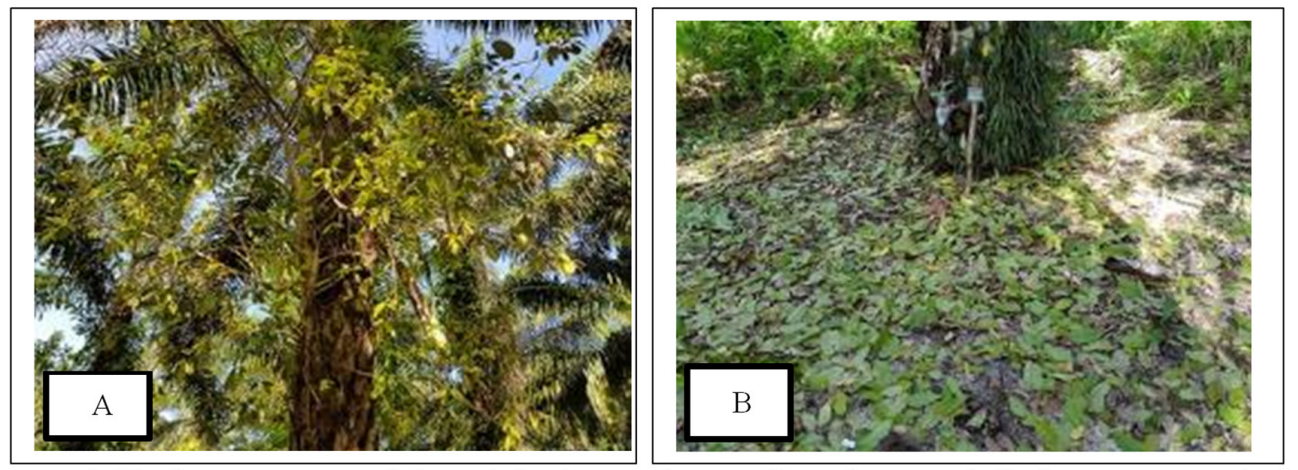

Figure 2. Early symptoms of the epiphytic weed mortality after root infusion treatment include leaf yellowing (A) and leaf drop (B)

Leaf symptoms in the form of chlorosis (yellowing) that inhibits the production of three amino acids and necrosis (brown and dead) usually appear one needed by plants, causing stunted growth and tissue to two weeks after herbicide application (Marble et death (Brown, 1990). Treatment using a mixture of al., 2016). Treatment of 30\% methyl metsulfuron (P2) showed higher mortality symptoms and was triclopyr showed lower mortality symptoms comsignificantly different compared to $20 \%$ methyl metsulfuron (P1), yet it was not significantly differpared to the treatment with methyl metsulfuron and glyphosate as active ingredients.

ent from the treatment of $40 \%$ methyl metsulfuron clopyr was less effective in controlling epiphytic (P3). Methyl metsulfuron is a systemic herbicide weeds compared to methyl and glyphosate treat- 

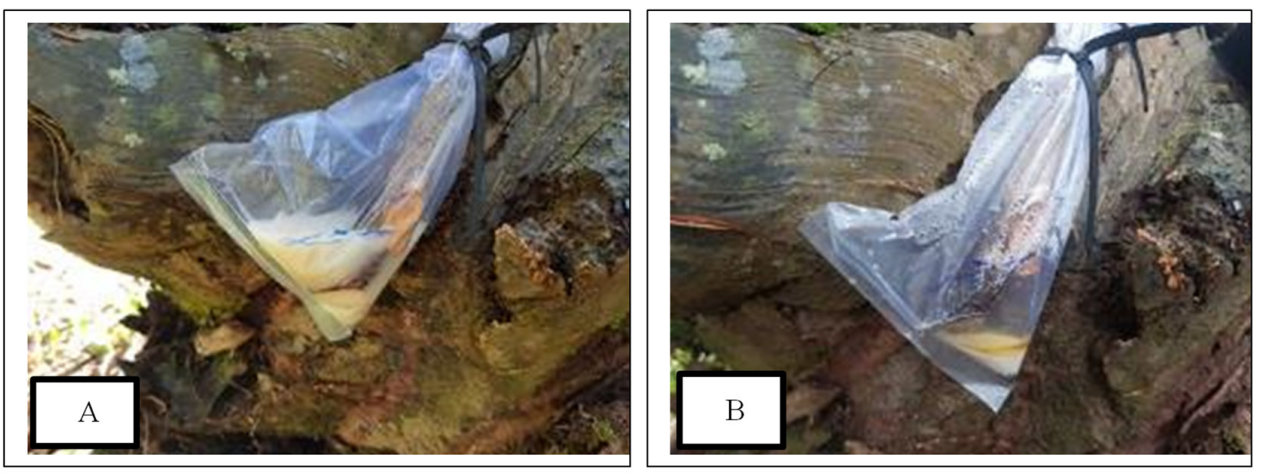

Figure 3. Absorption of methyl metsulfuron solution before $(A)$ and after $(B)$ an hour
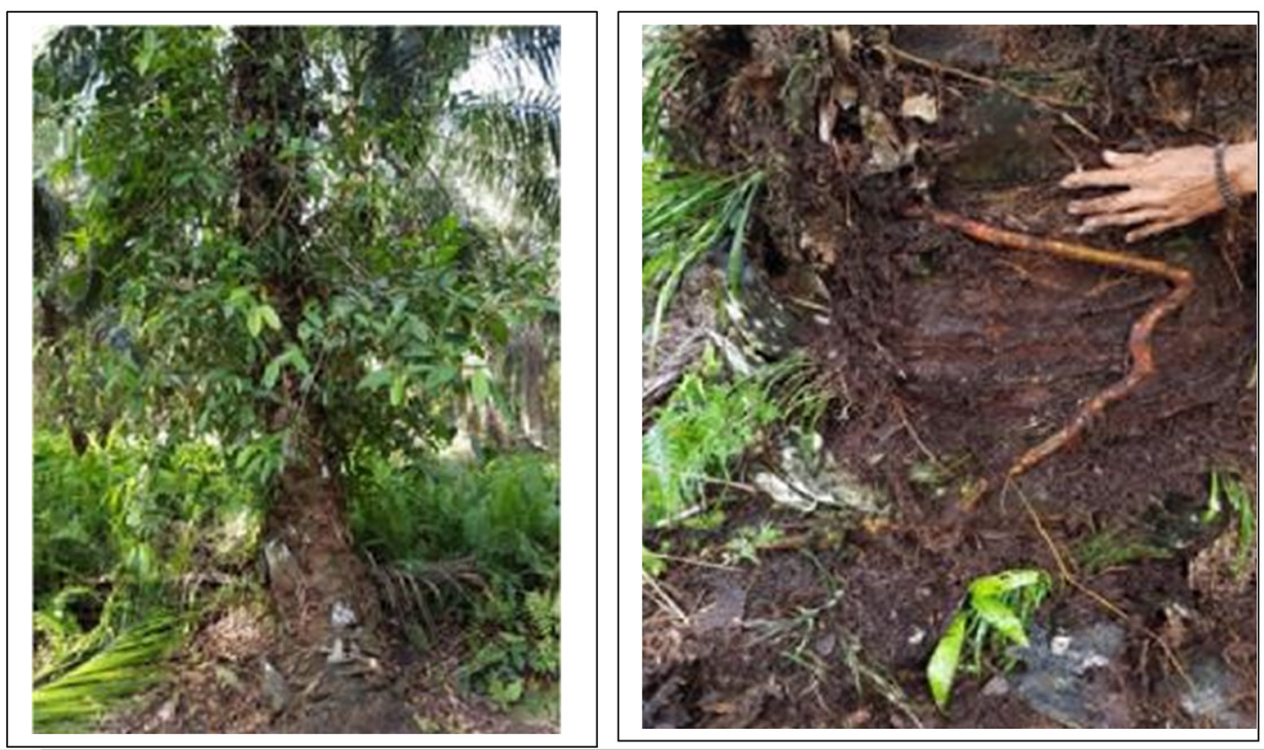

Figure 4. Survived epiphytic weeds due to their roots growing towards the soil

ments, indicated by lower mortality symptoms at four weeks after application. Further research is needed to determine the appropriate concentration of triclopyr and the combination with other active ingredients for epiphytic weed control.

One of the factors increasing the chance of weed mortality using the root infusion method is the absorption of the herbicide solution tied in a plastic bag. The absorption time of the herbicide solution can occur in a short time (one to 24 hours) (Figure 3). Once the herbicide solution has been entirely absorbed, the active ingredients are translocated to all weed tissues, causing death.

Epiphytic weeds that still had other roots grow- ing to the soil showed lower mortality symptoms compared to those whose roots had been completely cut off (Figure 4). The effect of herbicides can be less than optimal at low doses with large target plants and plant roots still having the ability to absorb water and nutrients from the soil (Hall et al., 1999). This root cutting causes the epiphytic weeds to absorb the liquid only from a mixture of herbicides in the plastic bag. Meanwhile, if other roots are not cut, the epiphytic weeds have a chance for recovery through the absorption of water and nutrients from the soil. However, the other roots are difficult to find since they are hidden between the gaps in the oil palm trunk. Epiphytic plants 
(banyan) are strangling plants whose roots are wrapped around the stem of the main plant. The roots grow towards the soil to absorb water and nutrients (Schmidt \& Tracey, 2006).

Epiphytic weed control with the root infusion method has advantages over the spray method in terms of safety for the applicator. If control is carried out using a spray technique, the applicator has the potential to be exposed to the applied herbicide solution since the position of the weeds is at the top of the oil palm trunk. The cost comparison of the active ingredients is shown in Table 2 . The most effective and economical treatment in controlling epiphytic weeds is glyphosate at a concentration of $30 \%$. Cutting and eliminating epiphytic weeds from the oil palm tree (Nufvitarini et al., 2016) as well as spraying herbicides containing active components of Dichlobenil and Atrazine to the leaves have been reported to be effective in controlling epiphytic weeds (Bartoli et al., 1993).

\section{CONCLUSION}

Treatment of glyphosate at a concentration of $30 \%$ was the most effective and efficient treatment in controlling epiphytic weeds. Cutting the entire suction root of epiphytic weeds can increase the chance of weed mortality.

\section{ACKNOWLEDGEMENTS}

The authors would like to thank the Management of PT Bumitama Gunajaya Agro for their support in conducting this research. All authors of this article declare no conflict of interest regarding the results of this study.

\section{REFERENCES}

Adibah, M.S.R. \& Ainuddin, A.N. (2011). Epiphytic Plants Responses to Light and Water Stress. Asian Journal of Plant Sciences, 10(2), 97-107. doi: 10.3923/ajps.2011.97.107

Ahmad, S. W., Jamili, \& Mustang. (2016). Keanekaragaman jenis burung pada areal perkebunan kelapa sawit di kecamatan Besulutu Kabupaten Konawe Sulawesi Tenggara. Biowallacea,
3(1), 312-320.

Bartoli, C.G., Beltrano, J., Fernandez, F.V., \& Caldiz, D.O. (1993). Control of the epiphytic weeds Tillandsia recurvata and Tillandsia aeranthos with different herbicides. Forest Ecology and Management, 59, 289 - 294.

Bayu, A., Hartutiningsih, \& Lugrayasa, I.N. (2004). Ekologi tumbuhan paku di taman nasional bogani nani wartabone, Sulawesi Utara. Laporan Teknis, Bagian Proyek Pelestarian, Penelitian dan Pengembangan Flora Kawasan Timur Indonesia, 84 - 89.

Brown, H.M. (1990). Mode of Action, Crop Selectivity, and Soil Relations of The Sulfonylurea Herbicides. Pesticide Science, 29, 125-130. doi: https://doi.org/10.1002/ps.2780290304

Compton, S.G., \& Musgrave, M. K. (1993). Host relationship of ficus burtt - davyi when growing as astrangler fig. South African Journal of Botany, 59(4), 425 - 430.

Essandoh, P.K., Armah, F.A., Odoi, J.O., Yawson, D.O., \& Afrifa, E.K.A. (2011). Floristic Composition and Abundance of Weeds in an Oil Palm Plantation in Ghana. ARPN Journal of Agriculture and Biological Science. 6(1): 20-31.

Ferwerda, J. D. 1977. Ecophysiology of Tropical Crops. Academic Press.

Ginting, K., Sutarta, E. S., \& Purba, R. Y. (2004). Pengendalian Gulma Epifit Pada Kelapa Sawit. Warta PPKS, 12(2-3), 23-27.

Hall, L., Beckie, H., \& Wolf, T,M. (1999). How Herbicides Work: Biology to Application. Alberta Agriculture and Rural Development. Canada.

Hengki, A., Soejono, A., Himawan, A. (2018). Pengendalian Ficus Benjamina dan Ficus Globosaa sebagai Gulma Parasit pada Kelapa Sawit dengan Beberapa Herbisida. Jurnal Agromast, 3 (1).

Kissinger, Pitri, R. M. N., \& Hamdani. (2016). Perubahan komposisi jenis vegetasi dan burung setelah penanaman kelapa sawit di lahan kering Pelaihari Kalimantan Selatan. EnviroScienteae, 12(1), 28-34. doi: http://dx.doi.org/10.20527/es.v12i1.1097

Kuvaini, A. (2011). Penentuan konsentrasi efektif herbisida prima up 480 sl dan meta prima 20 wdg untuk mengendalikan gulma beringin. Jurnal Citra Widya Edukasi, 3(1), 1 - 9.

Mangoensoekarjo, S. dan A.T. Soejono. (2015). Ilmu Gulma dan Pengelolaan pada Budi Daya Perkebunan. Gajah Mada University Press. Yogyakarta.

Marble, C. J., Smith, T.K. Broschat, A. Black, E. Gilman and C. White. (2016). Effects of

Metsulfuron Methyl Containing Herbicides on Ornamentals. School of Forest Resources and Conservation Department. Florida.

Nufvitarini, W., Zaman, S., \& Junaedi, A. (2016). Weed management of oil palm (Elaeis guineensis Jacq.) case: at south kalimantan. Buletin Agronomi, 4(1), 29 - 36.

Schmidt, S. \& Tracey, D.P. (2006). Adaptations of strangler figs to life the rainforest canopy. Functional Plant Biology, 33(5), $465-475$.

Seprido. (2020). Komunitas Burung pada Perkebunan Kelapa Sawit Rakyat di Kabupaten Kuantan Singingi. Bio-Lecture Jurnal Pendidikan Biologi, 7(2), 19-24. doi.org/10.31849/bl.v7i2.5078.

doi: https://

Simanjorang, F. J. (2013). Efektvitas pengendalian gulma beringin (Ficus benjamina sp) pada tanaman kelapa sawit (Elaeis guineensis Jacq) dengan cara infus akar di afdeling II kebun inti PT. Tasma Puja. Skripsi STIPAP Medan. 
Sofiyanti, N. (2013). The diversity of epiphytic fern on the oil palm tree (Elaeis guineensis Jacq.) in Pekanbaru, Riau. Jurnal Biologi, 17(2), $51-55$.

Starr, F., Starr, K., \& Loope, L. (2003). Ficus benjamina Weeping fig Moraceae. Biological Resources Division. Hawai. 